\title{
ISTRIAN FOLK NARRATIVE TRADITION FROM THE PERSPECTIVE OF CHANGING BORDERS
}

\author{
MONIKA KROPEJ
}

This paper focuses on the folk narrative tradition of Istria, which reflect the area's cultural landscape as well as the everyday life of its inhabitants. Presented is an overview of the changing narrative tradition in the area situated along presently disappearing formal state borders within the expanded European Union. The author explores older studies and research conducted by contemporary scholars who focused their scholarly interest in the spiritual culture of this area. Special interest is dedicated to the narrative tradition connected with cultural landscape, to traditional narratives as part of intangible heritage, as well as their role in overcoming ethnic as well as social and economic problems. Keywords: Istria, region, cultural landscape, ethnicity, border, folk narrative, intangible heritage, tradition, culture.
Članek obravnava ljudsko pripovedno izročilo Istre,v katerem odsevata kulturna krajina in vsakdanje življenje ljudi. Predstavljen je kratek pregled spreminjajočega se istrskega pripovednega izročila na tem območju, kjer danes s širitvijo Evropske unije formalne meje počasi izginjajo. Raziskava se opira na dela starejsih piscev, prav tako pa tudi na objave novejsih raziskovalcev in zbiralcev istrskega duhovnega izročila. Posebna pozornost je namenjena ljudskemu pripovednemu izročilu, povezanem s kulturno krajino, in vlogi, ki ga labko ima pri obranjanju kulturne podobe krajin ter oživljanju nesnovne dediščine, prav tako pa tudi pripreseganju etničnih, posredno pa tudi družbenih in ekonomskih problemov.

Ključne besede: Istra, regija, kulturna krajina, etničnost, meja, ljudsko pripovednistvo, nesnovna dedišcina, tradicija, kultura.

\section{A SHORT INTRODUCTION}

Istra/Istria is a European region with strong historic, cultural and strategic potential that is gaining in importance within the European Union. Its location in three countries - Croatia, Slovenia and Italy - accords Istria with a special status. The Istrian peninsula is located between the Gulf of Trieste/Trst and the Gulf of Rijeka/Fiume. In Italy it reaches from the Bay of Muggia/Milje to the Karst ridge. The Slovenian part of Istria now lies between the Rižana and Dragonja rivers since its southern border was moved from the Mirna river northwards due to Venetian colonisation. The largest, Croatian, part of Istria reaches from the Dragonja River into the Gulf of Rijeka.

The history of Istria was turbulent, and it got its name after the pre-Roman inhabitants Histri. The Slavs settled it as early as the 7th century, and the first document to testify to the presence of the Slavs in Istria was the "Rižana Placit" written in 804. In the Middle Ages, Istria was under the patriarch of Aquilea, while in the 13th and 14th centuries it was divided amongst the Venetians and Austrians. With the end of the Venetian Republic in 1797, and following the Napoleonic Illyrian Provinces, Istria together with Trieste fell under the Austro-Hungarian monarchy. This was a time of economic and cultural 
prosperity, a time of national awakening for Slovenians and Croats. After World War I, the Italian authorities started implementing an assimilation policy and systematically removed Slovenians from Trieste and its surroundings, and at the same time populating the entire Istria with immigrants from Italy. After the Second World War, between 1945 and 1956, as many as 25,000 - mostly Italian - inhabitants moved from the B zone (which was under the government of Yugoslavia $)^{1}$ to Italy for political reasons. The borders were determined on the basis of the London Treaty of 1954 and after fixing the borders between the former Yugoslav republics of Slovenia and Croatia. People from other Yugoslav regions immigrated to Istria. Thus Istria experienced radical demographic, economic as well as political change - the latest took place in 1991, when it was divided between the newly established states of Slovenia and Croatia. It is thus no wonder that the situation has not been settled here until today. ${ }^{2}$

\section{RESEARCHES OF ISTRIAN NARRATIVE TRADITION}

In the past, the concept of heritage was largely associated with tangible items - due in part to the UNESCO Convention of 1972 concerning the protection of the world's cultural and natural heritage that defined cultural heritage in terms of monuments, groups of buildings and sites (Nic Craith 2007: 2). This convention represented one of the reasons why researchers mainly dealt with the impact of the material elements of culture (Frykman 2002). This article will focus on folk narrative tradition as part of intangible heritage. Folk tales and legends reflect the cultural, political and economic past, while narratives that are told today also depict the present situation. Folk narrative tradition played an important role in Istria, and it is interesting that close communication between different ethnic groups here also influenced folk storytelling so that nowadays we can find many similarities and common motives in their folklore.

Polyhistor Johann Weichard Valvasor (was among the first who wrote about Istria and its people. In his 4-volume work Die Ehre des Herzogthums Krain (The Glory of the Duchy of Carniola), he made an inventory of all of Slovenia, including Istria (Valvasor 1689: VI, 335). In addition, the bishop of Novigrad, Giacomo Filippe Tommasini (Padua, 1595-Cittanova d'Istria, 1655), wrote about Istrian towns, their culture and history in the 17th century (Tommasini 1837). Italian writers such as Francesco Babudri (1926), Carlo de Franceschi (Gologorica near Pazin, 1807-1893), and Antonio Ive (1900) also made early accounts of these places. ${ }^{3}$

1 In 1945 the territory in the Northern Istria with "Morgan's line" was divided into the A-zone, under the command of "Alliance military administration", and B-zone, under the command of "Yugoslav military administration".

2 Main sources: Ravnik 2004; Darovec 1992.

3 More about this see: Bošković-Stulli 1959: 11-34. 
In the 19th century, Francesco Coronini - Cronberg, Alois Spinčić, and Peter Tomasini wrote about Istria for the pan-Austrian monumental collection Die Österreichisch-ungarische Monarchie in Wort und Bild - Das Küstenland (The Austro-Hungarian Monarchy in Word and Picture - Coastal Region, 1891). Furthermore, other collectors, especially priests and publicists, published folk tales at that time. Slovenian priest Jakob Volčič (Sv. Andrej nad Zmincem, 1815-Zarečje near Pazin, 1888), who was active in the suburbs of Pazin, was an important collector of folk tradition in Istria (Fikfak 1988). In the beginning of 20th century, important collectors and publicists such as Anton von Mailly (Gorica/Gorizia, 1874-Wien/Vienna, 1950), Giuseppe Vidossi (Koper/Capodistria, 1878-Torino, 1969), Italo Calvino (Santiago de Las Vegas, Cuba, 1923-Siena, 1985), and others including Achile Gorlato (1978), Elio Predonzani (1950), Giuseppe Radole (1969), and Giacomo Scotti (1960) collected a significant amount of folk narrative material. ${ }^{4}$

From the 1950s onwards, the most important researchers of folk tradition included Maja Bošković Stulli, Nikola Bonifačić Rožin, Ivo Jardas, and Olinko Delorko in Croatia as well as Milko Matičetov and Pavel Merkù in Slovenia. In 1949 and 1950, Milko Matičetov organized field research in Slovenian Istria, during which the ethnographers also collected folk songs and tales (Matičetov 1972: 131). The material is now archived mostly in the Regional Museum of Koper (Pokrajinski muzej Koper/Capodistria). Matičetov published three folk tales told by Bepo Umer - Malnar from the village Babiči by Marezige, who was his best storyteller in Istria (Matičetov 1963-64, among them: "Trije godci/Three Fiddlers" ATU 1654). Another folktale "Grgur in kosić/St.Gregor and Blackbird" (ATU $71^{*}$ ), which was collected by Matičetov in Osp near Črni Kal in 1949, was published by Boris Merhar (1956: 192). Among researchers working today are Tanja Perić-Polonijo, Lidija Nikočević, Luka Šešo, Laura Oretti, Roberto Dapit, Rožana Koštial, Nada Ravbar Morato, Špela Pahor, Nelda Štok Vojska and many others. Thus during the years a great amount of folk tales has been collected. It is not possible to present them all in this article, but a brief introduction will be made.

\section{ISTRIAN FOLK NARRATIVE TRADITION}

A narrative from the northern part of Istria, related to a place called Devin/Duino near Trieste (Mailly 1989: 161, 163; Ravbar Morato 2007: 86-90), is very well known among the many folk tales preserved in this region. Etymologically, the toponym Devin derives from the theonym deva (virgin, maiden). The castle stands on a steep, rocky slope, some 40 meters above the sea, and was built in the end of the 11th or beginning of 12 th century. A new, "upper" castle was added few centuries later. This area had been settled by the Slavs as early as 7 th or 8 th century. Folk tradition has it that there once lived a vicious knight

4 More about them see: Oretti 1994. 


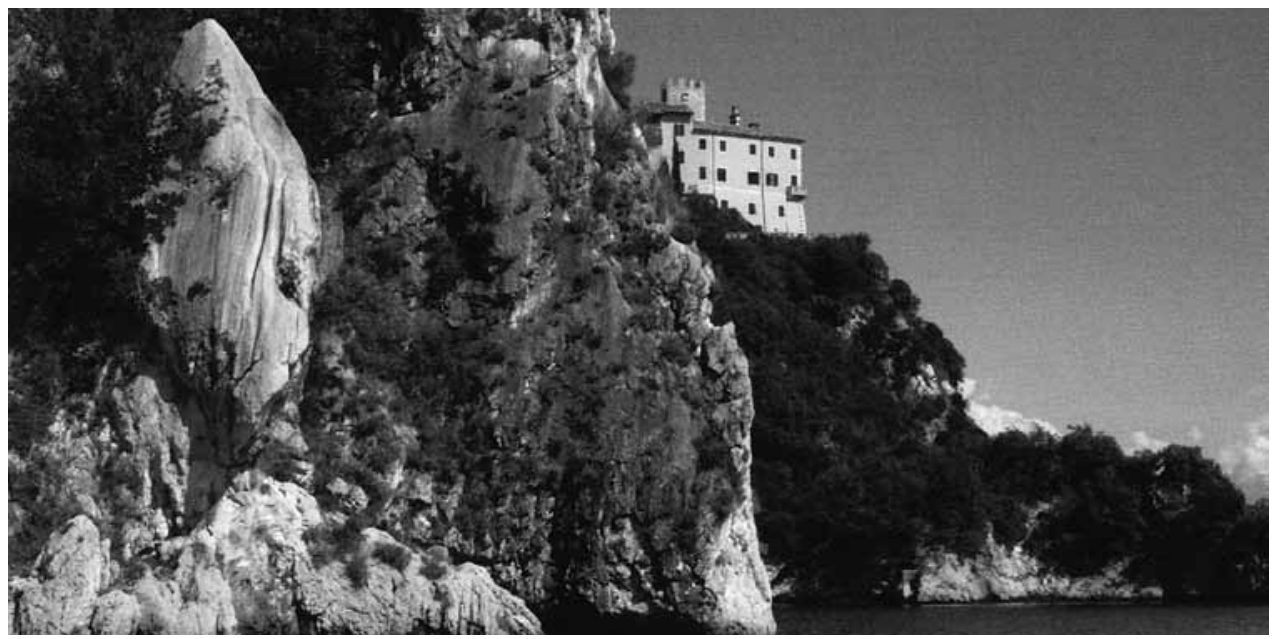

Figure 1. White Lady (la dama bianca) under the Old Castle of Devin/Duino.

in this castle who tried one night to push his wife over the cliff, but she petrified with fear (Cevc 1974: 99). In the 17th century, the historian Martin Bauzer wrote that they once used to throw white horses over the Devin (Duino) cliff as a tribute to the God of the Sea and the Beyond, whereby he probably resumed the story of the Greek hero Diomedes, who had allegedly arrived by sea to the Gulf of Trieste from Troy. The story itself belongs to the group of narratives about the devin skok (Virgin's Jump). Zmago Šmitek additionally explains it as a theonym that belongs to the concept of mythic landscape or the language of toponyms, which relates to the Slavic tripartite system: Mountain (abode of the sun god), River, and Devin skok (abode of the chtonic demon) (Šmitek 2004: 220). In this fashion Šmitek argues for an interpretation distinct from the one based on the obsolete dualistic concept used by Jan Peisker (1926) to interpret such toponyms.

The Croatian story "Grota svetog Stipana” (Saint Stephen's Cave) from Krasica near Buje also narrates a virgin's jump, except that in this story the defamed girl jumps from a high cliff after having recommended herself to Saint Stephen saying: "If I have sinned as they accused me, then let me die, but if I am innocent, let water that will heal people flow from underneath my feet!" And she stayed alive, and healing water flew from underneath her feet (Bošković-Stulli 1959, No. 68; 1986, No. 109).

Divić, on the other hand, presents the Arena of Pula (Pola) in Croatia, which has no connection whatsoever with a virgin, but rather with fairies. The amphitheatre in Pola was allegedly built by fairies (diva, deva, fairy), but because the cock crowed too soon, they were not able to add the roof (Bošković-Stulli 1959, No. 70).

For the origin of Buje people narrate that the ancient Slavs came there when there were no houses, and they stopped on top of the hill where the ancient town of Buje is located today and said: Tu bo buje (Here it will be better), and this settled their homestead (Bošković-Stulli 1959, No. 74). 
Istrian fairy tales are mostly variations of international folk tale types. In Slovenian Istria, Milko Matičetov identified about 50 different international folk tale types (Matičetov 1972), as did Maja Bošković-Stulli for the Croatian part of Istria (Bošković-Stulli 1959, 1986), while Laura Oretti, who analyzed published collections of Italian folk tales in Istria, classified them according to 150 diferent tale types (Oretti 1994). Yet these fairy tales have typical Istrian features. Thus, for example, the fearful gigantic monster in a story of the tale type ATU 328 “The Boy Steals the Ogre’s Treasure” (Bošković-Stulli 1959, No. 7) from the surroundings of Pula shared its name with the Istrian town of Umag. Although " $\mathrm{u}$ " is added, reminiscent of the town Umag, the name of the ogre probably derives from the word mag meaning 'mage' (Bošković-Stulli 1959: 161). In addition, Umago's adversary in the story - the youngest of the three brothers, Coto Perozin - is nick-named after the word cotav meaning 'lame' in the Istrian dialect.

Supernatural beings such as mrak (Nightfall) (Morato and Pahor 2002: 44), volkodlak (Werewolf), krsnik, vedavec / benandante, ujedenec (Ravbar Morato 2007: 38), štrigon, štriga (Witch), malik (Dwarf), orko (Orco) (Tomšič 1989: 35; Lipovec Čebron 2008 ), and kača pohišnica (house snake) (Matičetov 1972: 134) can be met throughout Istria. Valvasor (1689 IV: 335) already mentions mythical beings such as štrigoni and vedavci in Istria. Kresnik or krsnik holds a special place among them (Bošković-Stulli 1959, No. 160; Tomšič 1989: 47), and has assumed, on Slovenian territory, the image of a celestial thunder or sun god as well as some sort of shamanistic role of banandant in Italian folklore (Šmitek 2004: 137-178).

The Istrian goat has found its place in the coat-of arms of the town Koper since the name of the town derives from folk etymology from the Latin word for goat: capris $>$ Koper (Snoj 2009: 119). For this reason, the goat is a mascot of this region and is, among others, an icon of the vine industry (Vina Koper). The goat as a typical animal in these regions also appears in folk narratives.

People in the Italian, Slovenian as well as in Croatian areas of Istria narrated stories about Attila and his hordes of Huns and his deeds. Attila, the king of the Hunic tribes whom he united in 445, was called "the Scourge of God" and conquered Cividale and Aquilea. Slovenians narrated that Attila also built the castle of Udine and that he was buried in three coffins - one of gold, one of silver and one of copper - somewhere in the Tolmin area (Matičetov 1948, 1948/49). In addition, Attila's hidden treasures are often mentioned in Istrian folk belief legends (Morato and Pahor 2002: 11). Folk narrative also has it that in the village of Topolovec, they buried the dead from all over Istria who had died in numerous enemy invasions and epidemics around the church of Senžerolim (St. Hieronimus). A well known legend from Nadiška dolina/Val Natisione (Nadiža valley) is the narrative about the Slavic or Lombardian Queen Vida. She found shelter from Attila and his Huns in Landarska jama/Grotta di San Giovanni d'Antro, where she and her people resisted the siege by throwing down to Attila a sack full of corns, saying that they still had as many sacks of corn as there were grains in this sack (Mailly 1989: 239, note 143; Grimm and Grimm 1891, No. 466: Königin Adelheid; Aškerc 1889: 449). A tradition is preserved in this area as well as in Krivec about the story that Attila would 
bark three times like a dog before he spoke, and the same was narrated in Croatia (BoškovićStulli 1959: No. 88). There they also narrated that King Attila had one eye on his forehead, one on his cheek and one on his side (Bošković-Stulli 1959, No. 87). In Topolovec, people narrated that he had eventually been killed near Pazin, where he was stopped and burned with oil (Matičetov 1972: 132). The tradition that Attila was the son of a princess and a dog was generally spread both in Slovenia and Croatia, and also among the Italians in Istria (Scotti 1960; Oretti 1994: 238-244) as well as among Slovenians in Italy.5

It was a common tradition in Croatian, Slovenian and Italian Istria to warn children that they have to kiss a snivelling old woman - Baba - when they went to some places for the first time (Hrobat 2010). In the Italian part of Istria, parents warned their children that when they first went to Trieste, they must kiss the snivelling aunty (bešet strino šmrkavo). This is a frequent tradition also in the Slovenian littoral as well as in Upper Carniola, Venetian Slovenia, Friuli, Dalmatia, Macedonia and Liguria. This represented a sort of initiation, since this task had to be completed by children who first drove cattle to graze in the mountains or who first followed the commercial roads to Trieste (Ravbar Morato 2007: 58) or who went to school for the first time, etc. It appears that this tradition has its roots in the ancient notions of Baba (Golden Hag or Big Mother).

Like everywhere, these places too have their aetiological legends; thus, for example, in Dekani, they narrate "How did the Slovenians come to these places?"

When the Earth was all animals and desert, it called for workers; therefore God and Saint Peter sowed nations across the Earth. They had already distributed them all, and created Croats and others, when Peter felt in his pocket and found out that some seed had been left behind. It was ryegrass. Christ says: "Strew this across Karst!" And so Slovenians came out of ryegrass. (Matičetov 1972: 132)

Istria is the land of different nationalities who lived together and had different perceptions of each other. Many people in Istria made their living by selling their products in neighbouring countries. Like other women in Istria, the women from the village Dekani near Koper also used to transport different goods to other villages and towns. They transported firewood, milk, eggs, and the like by donkey to Trieste, where they were called šćave (It. schiavo, En. slave; vernaculat Italian derogatory for Slovenians and people of Slavic origin). When, however, they went towards Zagreb in Croatia to fetch food, they were called Talijanke (Italians), while Čiči called them Bezaki/Bezjaki (people from the Balkans who escaped before the Turks). As we can see, they were identified with three different nations, which shows how closely intertwined the population of this area was.

$\check{C}_{i}{ }_{c} i$ in Čičerija are a population that in the 16th century came from the Balkan peninsula that was devastated by wars and epidemics. They included Istro-Rumanians, Valachs, Čiči and Morlachs from Dalmatia, Lika and the Kvarner islands and settled throughout

Milko Matičetov recorded this legend in 1967 in Rezia (Mailly 1989: 239-299). 
central and southern Istria. ${ }^{6}$ Istrians used to sneer at them: $\check{C} i \check{c}$ ne da nič (Čič doesn't give a thing) or $\check{C} i \check{c}$ ni za barko (Čič is no good on a boat) (Matičetov 1972: 132).

The hard life of women even in the first half of the 20th century is illustrated by the story of a soon-to-be mother who drives a donkey loaded with firewood, cheese and other merchandise from Čičarija to Trieste. On her way, at Osp, her time comes. She stops only to give birth to the baby, leaves the new-born in the care of some people she knows, proceeds to Trieste, and on her way back picks up the baby (Matičetov 1972: 134-135). Frequent are narratives about the Šavrini and Šavrinke - Istrians living in the Šavrini hills (Šavrinsko gričevje) between Rižana and Dragonja rivers - who often made their living by transporting their goods and selling them in Trieste and other costal towns. Women (Šavrinke) in particular transported and sold egs, bread as well as milk and also washed the cloth for rich people in Trieste (Ledinek and Rogelja 2000). The tales about them and the Bezjaki (Croatians) are preserved in Slovenian as well as in Croatian lore (Bošković-Stulli 1986: No. 48, 63).

\section{NARRATIVE TRADITION AS PART OF CULTURAL HERITAGE}

After this very short introduction into Istrian story-telling, I will focus now on the preservation and enhancement of narrative tradition which could enrich the lives of different ethnic groups living in Istria and at the same time offer an authentic image of Istrian culture to visitors. The cultural landscape and monuments of Istria could be complemented by the memory of ancient traditions, which unfortunately are not being sufficiently revived and highlighted in present times. Even folk legends about Attila's castles, graves and treasures are not promoted, and one could almost say that they are disappearing from social memory. The settlement of Krkavče with the Stone of Krkavče and the castle Kaštel/Castelvenere, which rises so magnificently above the Dragonja river and the undulating Istrian landscape, remains unnoticed by the thousands of tourists passing by, despite the fact that it conceals in its ruins the memory of a turbulent history and life of the old colonists and cultures that have developed here. Even though archaeologists and other researchers have pointed out their importance (Puhar and Pleterski 2005; Cerar 2009: 214-219), it seems that once so important manors are being lost into oblivion together with other examples of rich cultural and narrative tradition that should be preserved in Istrian landscape and places.

Closer examination of preserved narrative tradition shows that those narratives that accompany custom and feast days are a little better off. Thus, for example, on Assumption Day, 15 August, a procession on boats from Piran has been revived in Strunjan in Slovenia, ${ }^{7}$

6 The name Čič has been used for very different immigrants, and both Istroromuni/Istroromanians and Vlahi/Vlachs are sometimes used synonimously; Morlaks are sometimes also named crni Vlahi, black Vlachs (http://www.istrapedia.hr/hrv/545/cicarija/istra-a-z/).

7 Pilgrimage to St. Mary's church in Strunjan on the boats, carrying the image of St. Mary, was first organized in 1912 and revived in 2005 by priest Niko Žvokelj. 


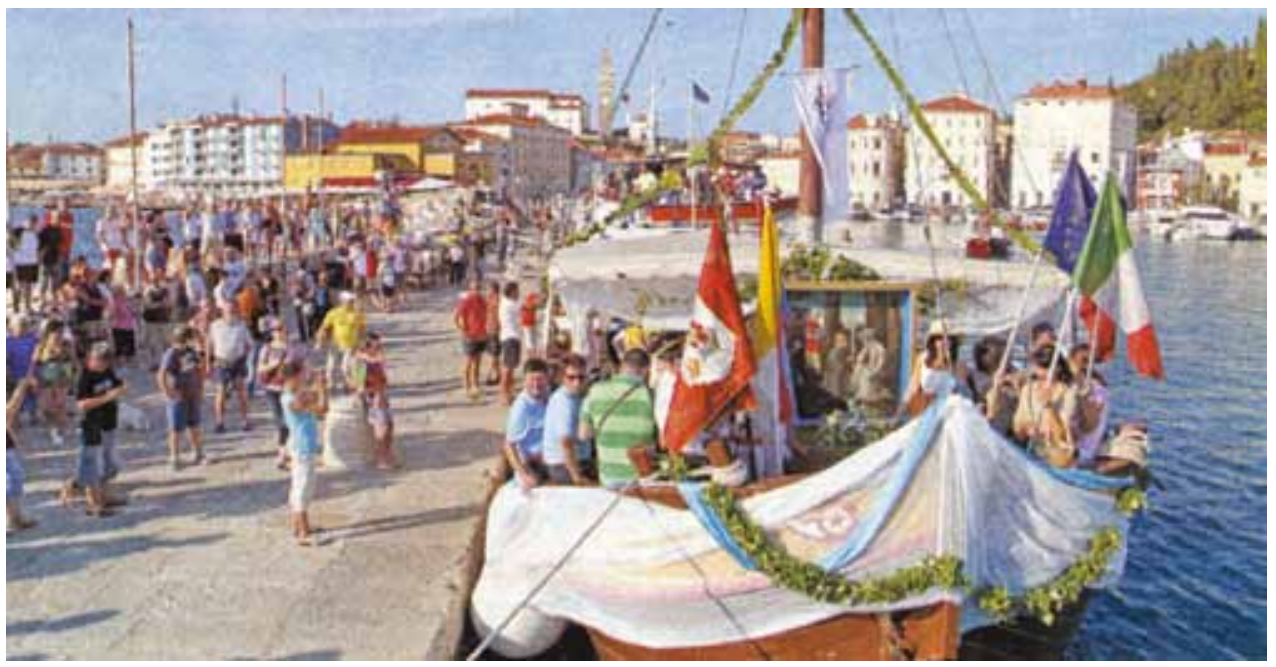

Figure 2. Pilgrimage on the boat, carrying the image of St. Mary back to Strunjan (Družina 34, 26. 8. 2012).

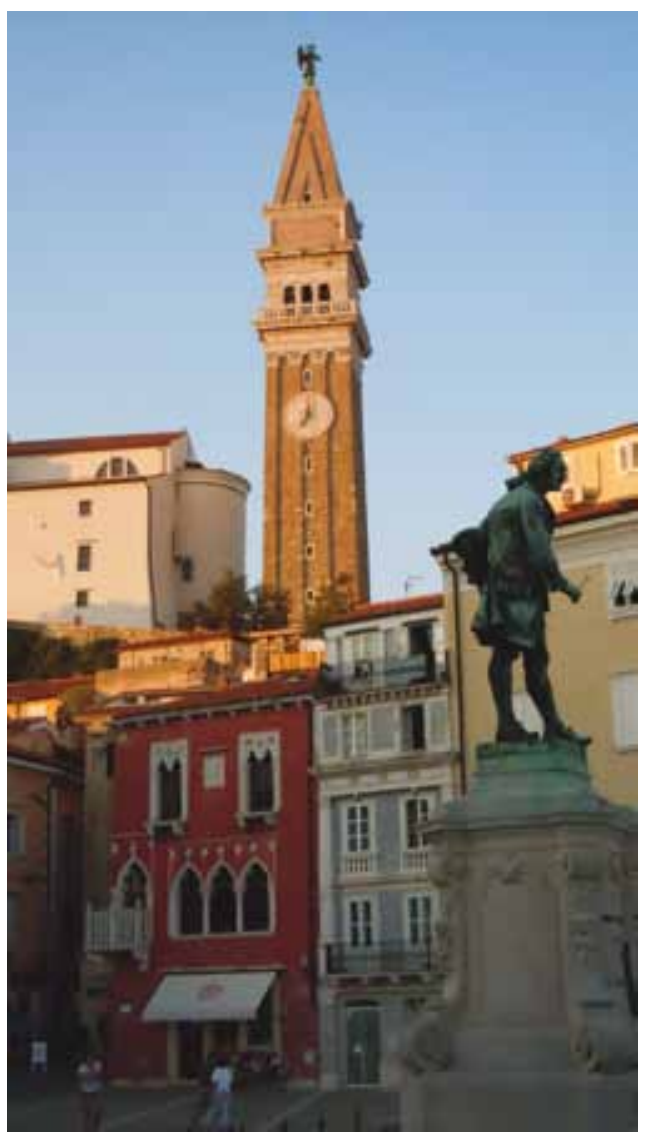

Figure 3. The red house in Piran "Benečanka" (Venetian lady) with the inscription Lasa pur dir (Let them speak) in the relief. which, in honour of St. Mary and her miraculous appearance, carry her image to its church on the top of a hill. The story has it that in the year 1512, St. Mary appeared in Strunjan before two guards in the vineyard asking them to repair her church, and so people built this church in her honour. She saved the lives of many seamen since then. Her footprints and the traces of her tears that she has cried in saving seamen from drowning can still be seen by the big cross of Strunjan (Kropej 2008: 443).

Another example of narrative tradition kept alive today is the contemporary legend from Piran that has survived because tour guides have included it into their tour of Piran: the "Venetian House" with the inscription Lasa pur dir (Let them speak), that tells the love story of a rich Venetian merchant and a beautiful Piranian maiden (Weber 2007: 162).

It is also helpful to the preservation of narrative tradition that local Croatian authorities have been organizing "Legendfest - festival narodnih priča, legendi i mitova Istre" (Legendenfest - Festival of folk tales, 


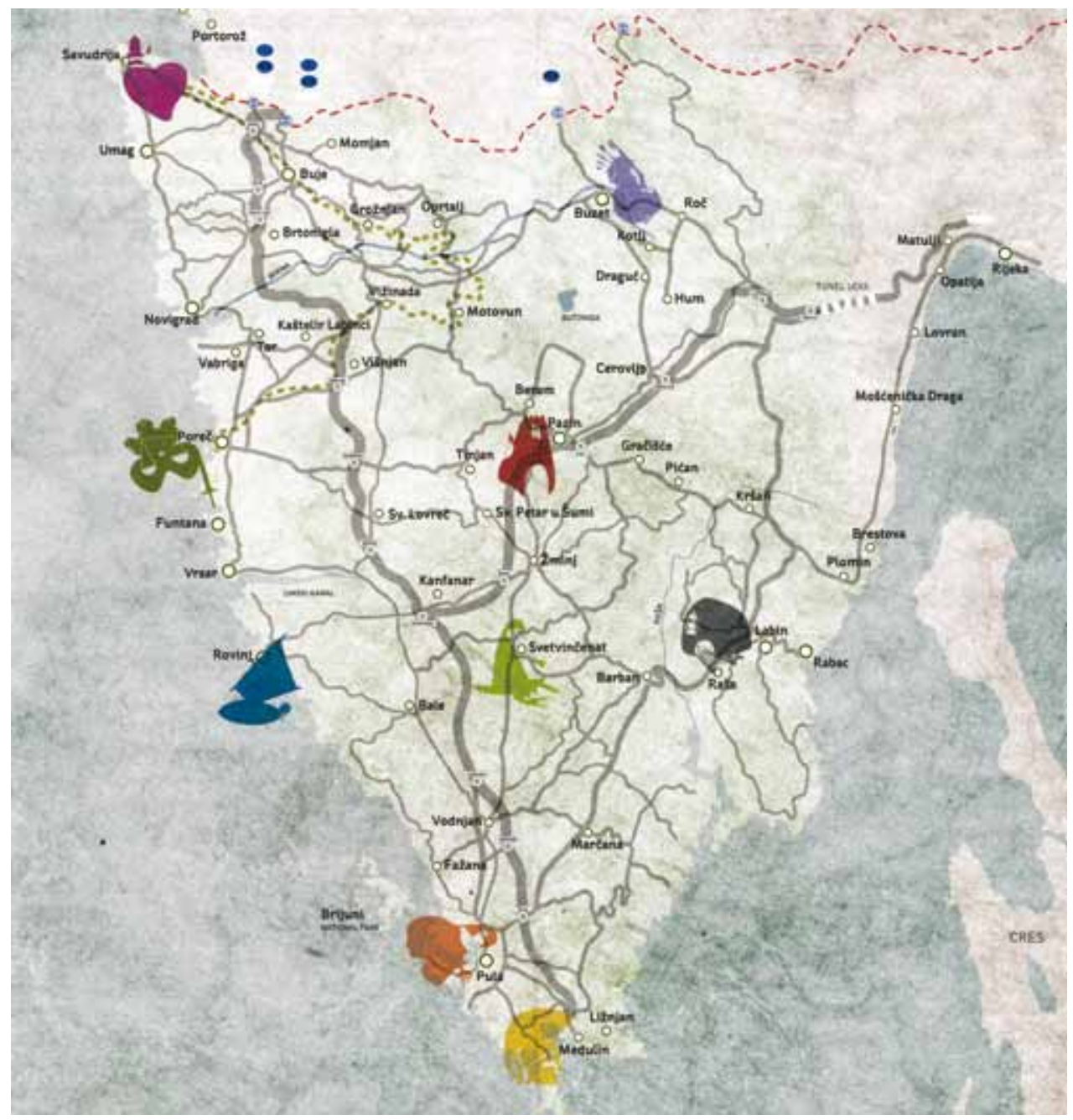

Figure 4. "Istrainspirit" links different organizations in Croatian Istria and advertises their cultural events connected with local narrative and historical tradition.

legends and myths of Istria) yearly from the year 2006 onwards - either at the end of July or beginning of August - in Pićan, the small town between Labin and Pazin under Učka mountain. ${ }^{8}$ After the event, they also publish a publication titled Legende i priče Istre (Legends and tales of Istria). It would be good if they stressed more existing regional and local traditions during this event because nowadays folk tales from all countries and nations are being told at akin festivals. The Croatian authorities are planning to establish in Pićan a Museum of Intangible Heritage, and this could be a good example for other cultural organizations and institutions in other parts of Istria.

At the University of Primorska in Koper, students can now enroll in a programme of "cultural and heritage tourism" and "heritage studies", which promote better understanding

8 See http://www.legendfest.hr/. 
and knowledge of Istrian tradition for young generations of students. Apart from this and varied festivals, cultural events, church feasts, fairs and other events organized by cultural or tourist organizations, folk narrative heritage is regretfully sinking into oblivion. People are making too little benefit of the rich spiritual culture of their ancestors and instead the presentation of natural and material wealth is still predominates: for instance, the preservation of local architecture and natural sites such as the saltpans in Sečovlje. Local institutions could, by focusing on spiritual culture and intangible heritage, enrich the area's cultural landscape. Already a notice board with a short description of a story and the illustration or description of the local site where the folk tale unfolds may represent a great step towards enlightening the population and introducing local heritage to tourists. By following the local patterns of culture, and improving the educational system - which is together with cultural politics one of the key institutions for keeping tradition alive the local authorities could more easily overcome existing political, ethnical and economic problems, and set better relations for the population that has been too often economically and politically suppressed.

Though tradition is already part of regional cultural presentation in Western Europe, this is not the case in Istria. Ulrich Kockel states that reflexive tradition understood as a process is potentially a progressive force and that for most regions across Europe, local culture and identity have been harnessed to provide foundations for social and economic growth and for the promotion of local and regional "heritage" as a resource, especially for tourism (Kockel 2007: 19). Though tradition does play a rather ambivalent role in the production of heritage, Istria should promote more forcefully its tangible and intangible heritage, including its folk narrative tradition, which clearly shows that changing borders did not result in the development of different narrative traditions in Istria. Pertti Anttonen claims that the cultural representations that are selected for making political claims of heritage are commonly called "traditions, with a special emphasis on their character as cultural properties, that is, representations with an ownership label" (Anttonen 2005: 39). But he also suggests that "to be traditional is to be modern in a different way" (2005: 40). In this way, Kockel suggested that "heritage means that elements of culture are no longer part of the active process of tradition (Kockel 2007: 29). This distinction between heritage and tradition does not diminish the potential which narrative tradition could have even though it could be used as part of intangible heritage in the Istrian region.

It is however true that people are trying today to appropriate history for various purposes; David Lowenthal calls attention to the fact that the past is now found everywhere and that it has been bent in such a way that it can be used as a reference in political argumentation as easily as in people's everyday lives (Lowenthal 1996: 247). But one can not generally disapprove of the efforts that have been made until now to preserve the cultural heritage and spiritual culture of different Istrian places. Moreover, much more should be done because the cultural landscape also needs to live its spiritual tradition, which enriches it and preserves its local and regional tradition before oblivion. 


\section{REFERENCES}

Anttonen, Pertti

2005 Tradition through Modernity: Postmodernism and the Nation-State in Folklore Scholarship. Helsinki: Finnish Literature Society (Studia Fennica, Folklorica; 15).

Aškerc, Anton

1889 Attila in slovenska kraljica. Ljubljanskizvon 9 (8): 449.

Babudri, Francesco

1926 Fonti vive dei Veneto-Giuliani. Milano: Trevisini.

Bertoša, Miroslav and Robert Matijašić (eds.)

2005 Istarska enciklopedija. Zagreb: Leksikografski zavod Miroslav Krleža.

Bošković-Stulli, Maja

1959 Istarske narodne priče. Zagreb: Institut za narodnu umjetnost.

1960 Kresnik-Krsnik, ein Wesen aus der kroatischen und slovenischen Volksüberlieferung. Fabula 3: 275-298.

1986 Zakopanozlato. Hrvatske usmenepripovijetke, predajei legende iz Istre. Pula: Čakavski sabor and Istarska naklada ; Rijeka: „Otokar Keršovani“ and Edit; Rovinj: Centro di ricerche storiche (Sedmo kolo; 38).

Calvino, Italo

1956 Fiabe italiane. Torino: Einaudi.

Cerar, Irena

2009 Pravljične poti vzodovino. Družinski izletniški vodnik. Ljubljana: Sidarta.

Cevc, Tone

1974 Okamenela živa bitja v slovenskem ljudskem izročilu. Traditiones 3: 81-112.

Darovec, Darko

1992 Pregled zgodovine Istre. Koper: Zgodovinsko društvo za južno Primorsko in Primorske novice (Knjižnica Annales; 1).

Fikfak, Jurij (ed.)

1988 Jakob Volčic in njegovo delo. Zbornik prispevkov in gradivo / Jakov Volčić i njegovo delo. Zbornik priloga i grade. Pazin in Ljubljana: Istarsko književno društvo »Jurija Dobrila«.

Frykman, Jonas

2002 Place for Something Else - Analysing a Cultural Imaginary. Ethnologia Europea 32 (2): 47-68.

Gorlato, Achille

1925 La Venezia Giulia, Trieste e Istria. Torino: Paravia.

1954 Vita Istriana. Venezia: Zanetti.

1978 Antiche leggende veneto-giuliane. Venezia: Tip. Helvetia.

Gorlato, Achille and Elio Predonzani

1951 I raconti delle notti lunari. Legende istriane. Torino: Paravia.

Grimm, Jacob and Wilhelm Grimm

1891 Deutche Sagen. 3. Aufl., besorgt v. Herman Grimm. 2 Teile in 1 Bd. Berlin: Nicolaische Verlags Buchhandlung (1. Aufl.: I: 1816, II: 1818).

Hrobat, Katja

2010 Ko Baba dvigne krilo. Prostor in čas v folklori Krasa. Ljubljana: Univerza v Ljubljani, Filozofska fakulteta (Razprave Filozofske fakultete).

Ive, Antonio

1888 Saggi di dialetto rovignese. In: Benussi, Bernardo, Storia documentata di Rovigno. Trieste: Tip. Del Lloyd Austro-Ungarico [appendix 5-78]. 
1900 I dialetti ladino-veneti dell'Istria. Strasburgo.

1993 Fiabe istriane (ed. critica a cura di L. Oretti). Gorizia: Editrice Goriziana.

Kockel, Ulrich

2007 Reflexive Traditions and Heritage Production. In: Kockel, Ullrich and Máiréad Nic Craith (eds.), Cultural Heritages as Reflexive Traditions. New York: Palgrave Macmillan, 19-33.

Kropej, Monika

1997 K vprašanju slovenskih in hrvaških značilnosti v ljudskem pripovedništvu Primorja in Istre. Traditiones 26: 271-282.

2008 Podoba ženskega lika v ljudskih verskih predstavah in šegah. In: Slavec Gradišnik, Ingrid and Helena Ložar-Podlogar (eds.), Čar izročila. Zapušcina Nika Kureta (1906-1996). Ljubljana: Založba ZRC (Opera ethnologica Slovenica) 427-455.

Ledinek, Špela and Nataša Rogelja

2000 Potepanja po poteh Šavrinke Marije. Ljubljana: Slovensko etnološko društvo (Knjižnica Glasnika SED; 32).

Lipovec Čebron, Uršula

2008 Krožere zdravja in bolezni. Tradicionalna in komplementarna medicina v Istri. Ljubljana: Filozofska fakulteta, Oddelek za etnologijo in kulturno antropologijo (Županičeva knjižnica; 24).

Lowenthal, David

1996 Possessed by the Past: The Heritage Crusade and the Spoils of History. New York: The Free Press.

Mailly, Anton von

1916 Mythen, Sagen, Märchen vom alten Grenzland am Isonzo.Volkskundliche Streifzüge. München: Hugo Schmidt Verlag.

1922 Sagen aus Friaul und den Julischen Alpen. Leipzig: Dietrich 'sche Verlagsbuchhandlung.

1989 Leggende del Friuli e delle Alpi Giulie (ed. critica a cura di M. Matičetov). 3. ed. ampliata. Gorizia: Editrice Goriziana.

Makarovič, Marija and Marta Košuta

2008 Ena duša in ena pamet. Škedenj: Slovensko kulturno društvo Ivan Grbec.

Matičetov, Milko

1948 O etnografiji in folklori zapadnih Slovencev. Slovenski etnograf 1: 9-56.

1948/49 Attila fra Italiani, Croati e Sloveni. Ce-fastu?24/25: 116-121.

1963-64 Pri slovenskih pravljičarjih. Bepo Malnar. Pionir 7: 202-203.

1972 Ljudsko pripovedništvo v slovenski Istri. In: Rad 17. kongresa Saveza udruženja folklorista Jugoslavije. Poreč 1970. Zagreb, 131-135.

Merhar, Boris

1956 Od kod Vodniku snov za basen Kos in brezen? Slovenski etnograf9: 187-196.

Morato, Nada and Špela Pahor

2002 Mrak eno jutrnja. Štorje iz Slovenske Istre. Ljubljana: Kmečki glas (Glasovi; 25).

Nic Craith, Máiréad

2007 Cultural Heritages: Proces, Power, Commodification. In: Kockel, Ullrich and Máiréad Nic Craith (eds.), Cultural Heritages as Reflexive Traditions. New York: Palgrave Macmillan, 1-18.

Nikočević, Lidija

$2008 I z$ »etnološkog mraka«. Avstrijski etnografski tekstovi o Istri s kraja 19. i početka 20. stoljeća. Pula:

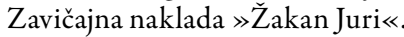

Oretti , Laura

1994 Acaminando che , l va.... Repertoario della narrativa di tradizione orale delle comunita Italiane in Istria. Trieste: Italo Svevo 
Peisker, Jan

1926 Tvarog, Jungfernsprung und Verwandtes. Blätter für Heimatkunde 4 (7-8): 49-57.

Perić-Polonijo, Tanja

1997 Hrvatske Narodne pjesme što se pjevaju u Istri I na Kvarnerskih otocih (Preštampane iz "Naše sloge" potporom "Matice hrvatske"). Pazin: Istarsko književno društvo "Juraj Dobrila".

Predonzani, Elio

1950 Motivi delle leggende istriane. Pagine istriane s. III, a. I, no. 4.

Puhar, Jana and Andrej Pleterski

2005 Krkavški kamen v ustnem izročilu in v sklopu obredne prostorske strukture. Studia mythologica Slavica 8: 57-74.

Radole, Giuseppe

1969 Fiabe istriane raccolte a Barbana. Trieste: Comunita Istriane.

1977 Settanta nuove fiabe istriane. Trieste: Italo Svevo.

Ravbar Morato, Nada

2007 Krub in ribe. Od Bržanije prek Trsta do Soče. Celje: Mohorjeva družba (Glasovi; 32).

Ravnik, Mojca and Zvona Ciglič

2004 Istra. In: Baš, A. (et al., eds.), Slovenski etnološki leksikon. Ljubljana: Mladinska knjiga, s. v.

Rutar, Simon

1899 Beneška Slovenija. Prirodoznanski in zgodovinski opis. Ljubljana: Slovenska matica.

Scotti, Giacomo

1960 Attila nelle leggende del popolo istriano. Panorama 9 (2): 16-17.

1976 Storie istriane. Milano: Fratelli Fabri.

Snoj, Marko

2009 Etimološki slovar slovenskih zemljepisnih imen. Ljubljana: Modrijan.

Śmitek, Zmago

2004 Mitološko izročilo Slovencev. Svetinje preteklosti. Ljubljana: Študentsak založba.

Štok - Vojska, Nelda

2005 Istrske štorijce. Koper: Libris.

Tomasetig, Ada

1985 Pravce, ki so se v košu rodile, $v$ Benečiji živele in $k$ nam prišle. Trst: Založništvo tržaškega tiska; Ljubljana: Borec.

Tommasini, Giacomo Filippo

1837 Costumanze nell' Istria. Nei Commentari Storici-Geografici della Provincia dell'Istria. Archeografo Triestino vol. IV. Trieste.

Tomšič, Marjan

1989 Nočje moja, dan je tvoj. Istrske štorije. Ljubljana: Kmečki glas (Glasovi; 2).

Valvasor, Johann Weichard

1689 Die Ehre des Herzoghtums Krain I-IV. Laibach \& Nürnberg.

Vidossi, Giuseppe

1910 Leggende d'Attila in Istria. In: Miscellanea di studi in onore di Attilio Hortis II. Trieste: Il comitato promotore, 1023-1037.

1936 Popolaresca. Ceni sullo studio delle tradizioni popolari. In: Chirone. Manuale di cultura popolare. Trento: Ufficio di Trento, 443-468.

Weber, Irena

2007 Heritage Narratives on the Slovenian Coast: The Lion and the Attic. In: Kockel, Ullrich and Máiréad Nic Craith (eds.), Cultural Heritages as Reflexive Traditions. New York: Palgrave Macmillan, 19-33. 


\section{ISTRSKA PRIPOVEDNA TRADICJA SKOZI PERSPEKTIVO SPREMINJAJOČIH SE MEJ}

V prispevku je obravnavana duhovna kultura Istre, predstavljen je pregled nad spreminjajočo se istrsko pripovedno tradicijo na jadranskem območju mej treh držav: Hrvaške, Slovenije in Italije. Študija se opira na dela starejših piscev in zbiralcev, prav tako pa tudi na gradivo, $k i$ so ga zbrali sodobni raziskovalci, katerih znanstveni interes je duhovna kultura tega območja. Posebna pozornost je namenjena kulturni krajini ter nesnovni dedišcini in njunemu pomenu tudi pri razpravah o premagovanju političnih, etničnih in ekonomskih težav.

$V$ Evropi postajajo regije use pomembnejše, pri tem pa imajo regije, kakršna je na tri države razdeljena Istra, še poseben položaj. Istra je polotok med Tržaškim in Reškim zalivom in sega v Italiji od Miljskega zaliva do Kraškega roba; slovenski del Istre je danes med Rižano in Dragonjo, najobsežnejši, hrvaški del Istre sega od Dragonje do Reškega zaliva. Stari istrski prebivalci so bili Histri, Slovani so poselili te kraje v 7. stoletju. Prva listina, ki potrjuje slovansko poselitev v Istri, je Rižanski placit iz leta 804.

Med prvimi, ki so pisali o Istri in ljudeh, ki so tod živeli, je bil polihistor Janez Vajkard Valvasorv delu Slava Vojvodine Kranjske (1689: VI, 335ss). Prav tako v 17. stoletju je novigrajski škof Giacomo Filippo Tommasini pisal o istrskih mestih, njihovi kulturi in zgodovini. Med italijanskimi pisci sta o teh krajih poročala npr. Francesco Babudri in Carlo de Franceschi. Sledili so številni drugi raziskovalci in tako je danes zbrano bogato in raznovrstno gradivo tudi o istrkkem pripovednisttun. Številne pripovedi so vezana na določene kraje in zgradbe, pripovedujejo o antičnih in drugih spomenikih in znamenitostih, prav tako pa tudi o zgodovinskih premikih in napadih Hunov, Langobardov, Francozov ter o različnih poselitvah. Številne so tudi pravljice, bajke, legende ter etioloske in druge povedke, ki pogosto pripovedujejo o življenju in navadah etnično izjemno pisanega istrskega prebivalstva.

Kulturno krajino Istre spremlja spomin na starodavno izročilo, vendar je to danes, žal, premalo oživljeno in poudarjeno. Ustno izročilo se ohranja predvsem na kulturnih prireditvah ob obredjih in cerkvenih šegah, ki oživljajo nekatere stare legende. Tudi festivali pripovedovanja pravljic, kakršen je zdaj že tradicionalni "Legendfest (od leta 2006) v Pićanu pri Pazinu, prispevajo $k$ ohranjanju ljudskega pripovednega izročila teh krajev; prav tako tudi objave pripovednega in pesniskega izročila. Premalo pa sta razvita kulturno ozavešcanje ljudi in kulturni turizem, saj bi turistične agencije in kulturne ter občinske organizacije labko naredile veliko več. Tako, žal, nesnovna dedišcina zaenkrat še vedno tone v pozabo. Ljudje ne poznajo dovolj bogastva duhovne kulture svojih prednikov. Z večjim poudarkom kulturi in lokalni duhovni dedišcini ter folklori bi lažje premagovali politične, etnične in gospodarske težave in rušili meje tam, kjer je bilo prebivalstvo, prepogosto gospodarsko in politično zatrto. Res je, da skušajo danes uporabljati zgodovino in kulturo $v$ raznovrstne namene, vendar pa mora kulturna krajina živeti tudi svoje duhovno izročilo, da ohrani svoji lokalno in regionalno tradicijo.

Dr. Monika Kropej, research advisor, ZRC SAZU Institute of Slovenian Ethnology, Novi trg 2, SI - 1000 Ljubljana, Slovenia, monika@zrc-sazu.si 